\title{
PENGEMBANGAN INSTRUMEN PENDETEKSI PEMAHAMAN WACANA SISWA TENTANG ATOM
}

\author{
Helda Verawahyuni ${ }^{1}$, Suyono $^{2)}$, Erma $^{3)}$ \\ ${ }^{1)}$ Mahasiswa Program Studi Pendidikan Sains, Program Pascasarjana Universitas Negeri Surabaya \\ ${ }^{2), 3)}$ Dosen Pascasarjana Prodi Pendidikan Sains Univesrtitas Negeri Surabaya \\ E-mail: helda_vw11@yahoo.co.id
}

\begin{abstract}
This study aimed to obtain instrument to detect student's comprehension text on the atomic structure of eligible on validity, reliability, and clarity in the language. The required of validity include: construction, content, psychometric, and predictive validity, and use simple language (straightforward). This instrument was developed following stages: (1) the development of specifications test, (2) writing a matter, (3) a review a matter, (4) assembly a matter (for testing purposes), (5) the trial tests, (6) items analysis, and (7) the selection and assembly matter. The variables in this study include: construct, content, clarity of sentences and grammar, psychometric (item validity, difficulty index, different power, and reliability), and predictive validity. To getting the predictive variables are needed another variable that distinguished the predictor variables and the criterion variable. Predictor variables consist of the ability of perception on the structure of atoms and the criterion variable is the number of misconceptions students on the concepts of atomic structure. The subject of research for content validity, construct and directness languages are experts in relevant fields to the product of developed instrument, who are 4 (four) chemistry lecturer for instruments which is includes chemistry concepts. The subject of research for psychometric and predictive validity is 130 students of class XI on SMAN 1 Sumberrejo and SMAN Model Terpadu, Bojonegoro. Connectivity test to measure comprehension text to the number of misconceptions experienced by students was done using descriptive and inferential analysis used X2 test. The results showed that instrument to detect student's comprehension text was feasible on validity (construction, content, and linguistic), psychometric, reliability, and predictive validity.
\end{abstract}

Keywords: Comprehension Text, Validity, and Reliability

\begin{abstract}
Abstrak: Penelitian ini bertujuan untuk memperoleh intrumen pendeteksi pemahaman wacana siswa pada struktur atom yang memenuhi syarat validitas, reliabilitas, dan kelugasan dalam bahasa. Validitas yang dipersyaratkan meliputi validitas konstruksi, validitas isi, validitas psikometrik, dan validitas prediktif, serta menggunakan bahasa yang sederhana (lugas). Intrumen ini dikembangkan mengikuti tahapan: (1) pengembangan spesifikasi tes, (2) penulisan soal, (3) penelaahan soal, (4) perakitan soal (untuk keperluan uji coba), (5) uji coba tes, (6) analisis butir soal, dan (7) seleksi dan perakitan soal. Variabel dalam penelitian ini antara lain: validitas konstruk, validitas isi, kelugasan kalimat dan tata tulis, validitas psikometrik (validitas butir, indeks kesukaran, daya beda, dan reliabilitas), dan validitas prediktif. Untuk mendapatkan variabel prediktif dibutuhkan variabel lain yang dibedakan atas variabel prediktor dan variabel kriterium. Variabel prediktor terdiri atas kemampuan siswa memahami wacana pada struktur atom dan sebagai variabel kriterium adalah jumlah miskonsepsi siswa pada konsep-konsep struktur atom. Subyek penelitian untuk validitas isi, konstruk dan kelugasan bahasa adalah para ahli di bidang yang relevan dengan produk instrumen yang dikembangkan, yang dalam penelitian ini adalah 4 (empat) orang dosen kimia untuk instrumen yang di dalamnya memuat konsep-konsep kimia. Subjek penelitian untuk validitas psikometrik dan validitas prediktif adalah 130 orang siswa kelas XI dari SMAN Sumberrejo dan SMAN Model Terpadu, kabupaten Bojonegoro. Uji keterhubungan data ukur pemahaman wacana siswa terhadap data ukur jumlah miskonsepsi yang dialami siswa dilakukan secara diskriptif dan secara inferensial menggunakan uji X2. Hasil penelitian menunjukkan bahwa intrumen pendeteksi pemahaman wacana siswa telah memenuhi validitas logis (validitas konstruksi, validitas isi, dan kebahasaan), validitas psikometrik, reliabilitas, dan validitas prediktif.
\end{abstract}

Kata kunci: Pemahaman Wacana, Validitas, Reliabilitas

\section{PENDAHULUAN}

Pemahaman wacana adalah salah satu unsur pembentuk model mental yang dimiliki siswa (Veer dan Melguizo di dalam Laliyo, 2011). Model mental yang dimiliki siswa mempengaruhi konsepsinya (Domin, 2000; Wang, 2007). Pemahaman wacana siswa tentang atom akan mempengaruhi keberhasilan atau ketidakberhasilan siswa memahami konsep-konsep pada struktur atom. Konsep-konsep dalam struktur atom yang seharusnya dipahami dengan model mental kuantum (model Q) akan gagal dipahami oleh siswa yang memiliki model mental yang lain, misalnya model mental Bohr (model B). Siswa yang memiliki model mental B umumnya mengalami miskonsepsi saat 
memahami konsep-konsep dalam struktur atom yang memerlukan model mental Q untuk memahaminya.

Konsep-konsep pada kajian struktur atom tergolong konsep yang sering dipahami miskonsepsi oleh sejumlah besar siswa (Park, 2006; Foliaki, 2005; Al-Balushi, 2012; MacKinnon, 2013). Topik struktur atom merupakan salah satu topik kimia yang kaya dengan entitas abstrak, sehingga berpeluang besar dipahami miskonsepsi oleh siswa. Perbaikan siswa miskonsepsi adalah upaya urgen, karena jika tidak dilakukan siswa akan mengalami kesulitan-kesulitan lanjutan, seperti kegagalan memahami konsep yang lain, serta memperoleh kebermaknaan dalam belajar (Dahar, 2011). Upaya perbaikan miskonsepsi siswa telah banyak dilakukan peneliti. Suyono dkk. (2013) juga telah melakukan perbaikan miskonsepsi siswa SMA pada sejumlah konsep kimia melalui program remedial teaching berbasis strategi conseptual change. Penelitian ini dilakukan dengan sasaran siswa dari 6 (enam) SMA Negeri yang masing-masing mewakili kota/kabupaten Surabaya, Gresik, Sidoarjo, Bojonegoro, Jombang, dan Sumenep. Program remedial teaching yang dilaksanakan secara klasikal ini masih belum memberikan hasil yang maksimal karena belum memberikan perhatian kepada karakteristik individual siswa yang mengalami miskonsepsi. Penelitian yang dilakukan Suyono dkk. (2014) menemukan sejumlah siswa yang mengalami miskonsepsi kimia resisten. Siswa dinyatakan mengalami miskonsepsi resisten adalah siswa miskonsepsi setelah mengikuti pembelajaran preventif dan juga setelah mengikuti pembelajaran remediasi.

Perbaikan miskonsepsi nampaknya harus memberikan perhatikan kepada karakteristik individual, salah satunya adalah model mental yang dimiliki siswa (Bao \& Redish, 2001). Seperti telah disebutkan sebelumnya, salah satu atribut model mental adalah kemampuan siswa memahami wacana. Perbaikan miskonsepsi siswa nampaknya perlu dicoba dengan memberi perhatian kepada karakteristik siswa berbasis kepada kemampuan memahami wacana. Terdapat argumentasi baik secara teoretis maupun empiris yang membuktikan adanya keterhubungan antara kemampuan siswa memahami wacana dan peluang mengalami miskonsepsi.

Dalam kaitannya dengan pemahaman wacana, adanya konsep-konsep abstrak dalam teks ilmiah mejadikan siswa tidak mudah memahami isi dari wacana itu (Best \& Ozuru, 2005; Lien, 2013). Tidaklah mengherankan jika kemudian ditemukan sebagian besar siswa di kelas tidak memiliki pemahaman atas isi teks yang dibacanya. Ketika siswa tidak memiliki pemahaman yang cukup dari suatu konsep tertentu, siswa sering memiliki masalah ketika menarik simpulan yang mencoba menghubungkan konsep-konsep yang ada di dalam kalimat-kalimat pembangun teks. Akibatnya, pemahaman siswa tentang teks tetap terfragmentasi dan menyebabkan kegagalan dalam membentuk representasi mental yang koheren dari isi teks secara keseluruhan dan hal ini dapat menyebabkan miskonsepsi. Ibrahim (2012) menjelaskan salah satu penyebab miskonsepsi adalah penguasaan konsep yang tidak lengkap. Selain itu bahasa yang digunakan dalam teks seringkali berbeda dengan bahasa sehari-hari siswa, sehingga siswa mengalami kesulitan dalam mengasimilasi informasi baru ke dalam struktur pengetahuan yang dimiliki siswa sebelumnya, dan pada akhirnya siswa tidak berhasil membangun representasi mental yang bermakna (Lien, 2013). Sebagai ilustrasi, ketika prakonsepsi siswa tentang pergerakan matahari salah (miskonsepsi) sangat dimungkinkan siswa gagal untuk memahami teks tentang tata surya secara akurat karena siswa tidak dapat mendamaikan informasi yang tercantum dalam teks dengan latar belakang pengetahuan yang sudah ada sebelumnya di dalam struktur kognitif siswa, pengetahuan yang diperoleh siswa dari pengalaman persepsi sehari-hari. Penggunaan prakonsepsi yang sudah ada sebelumnya (misalnya, latar belakang pengetahuan yang salah) dalam memahami wacana dapat menimbulkan terbangunnya sebuah model mental yang tidak akurat, yang berbeda dengan model ilmiah yang dimaksudkan oleh penulis teks (Chi et al., 1994). Prakonsepsi seperti itu dapat menimbulkan apa yang disebut Horton (2004) sebagai asimilasi dari informasi yang masuk ke struktur pengetahuan yang sudah ada sebelumnya, bukan akomodasi struktur pengetahuan.

Ibrahim (2012) mencoba menjelaskan pengaruh prakonsepsi dan pemahaman konsep dalam wacana. Menurut Ibrahim seringkali siswa berpikir dan mengasosiasikan konsep yang sedang dipikirkannya dengan sesuatu yang lain yang justru akan menyebabkan miskonsepsi.

Telah diuraikan bagaimana pemahaman wacana mempengaruhi konseptualisasi siswa. Kegagalan memahami wacana dapat menimbulkan terbangunnya sebuah model mental yang tidak akurat tentang suatu konsep. Dengan kata lain faktor penyebab miskonsepsi siswa dari perspektif model mental di antaranya adalah pemahaman terhadap wacana. Implikasinya adalah bahwa dalam pengambilan kebijakan-kebijakan terkait dengan perbaikan miskonsepsi siswa yang mempertimbangkan model mental, guru atau pendidik harus melihat faktor penyebab ini. Untuk dapat mengklasifikasi atau mengkategori siswa ke dalam level-level pemahaman wacana rendah, sedang, atau tinggi diperlukan data ukur kemampuan pemahaman wacana siswa. Untuk mendapatkan data ukur ini diperlukan instrumen pendeteksi pemahaman wacana siswa yang valid dan reliabel. Validitas yang harus 
dipenuhi meliputi validitas konstruksi, validitas isi, validitas psikometrik, dan validitas prediktif. Instrumen yang baik harus memiliki daya ukur yang konsisten atau ajek (reliabel). Instrumen yang memerlukan keterlibatan siswa untuk membacanya harus menggunakan bahasa yang sederhana (lugas) dan memiliki tingkat keterbacaan yang baik.

Saat ini belum tersedia instrumen pendeteksi kemampuan pemahaman wacana siswa pada struktur atom yang telah memenuhi syarat sebagaimana disebutkan pada alinea di atas. Untuk itu penting untuk dikembangkan instrumen itu melalui paradigma riset. Karena intrumen ini harus divalidasi kemampuan prediksinya terhadap konsepsi siswa pada struktur atom, maka bersamaan dengan pengembangan instrumen pendeteksi pemahaman wacana siswa juga dikembangkan intrumen pendeteksi konsepsi atau miskonsepsi siswa. Masalah yang akan dijawab melalui penelitian ini adalah "Bagaimana kualitas instrumen pendeteksi pemahaman wacana siswa yang dikembangkan?" Tujuan yang ingin dicapai dalam penelitian ini adalah untuk memperoleh intrumen pendeteksi pemahaman wacana siswa pada struktur atom yang memenuhi syarat validitas, reliabilitas, dan kelugasan dalam bahasa. Validitas yang dipersyaratkan meliputi validitas konstruksi, validitas isi, validitas psikometrik, dan validitas prediktif, serta menggunakan bahasa yang sederhana (lugas).

Validasi konstruk ditujukan untuk mengetahui kelayakan butir-butir pertanyaan dalam suatu daftar (konstruk) pertanyaan dalam menggambarkan apa yang hendak diukur. Untuk memenuhi validitas konstruk ini terlebih dahulu harus didefinisikan atau diidentifikasi ranah isi perilaku konstruk teoritis terkait dengan kemampuan memahami wacana. Pekerjaan ini ditempuh dengan strategi khusus yang disebut eksplikasi konstruk (Supratiknya, 2014). Jadi, eksplikasi konstruk terhadap suatu atribut psikologis diawali dengan perumusan definisi konseptual atau definisi teoritis tentang pemahaman wacana. Rumusan konseptual yang masih abstrak tersebut kemudian dikonkritkan dengan cara merumuskan definisi operasionalnya. Inti perumusan definisi operasional adalah mengidentifikasi indikator keberadaan atribut yang menjadi sasaran pengukuran. Dengan demikian kisi-kisi (konstruksi) yang dihasilkan berisi rancangan perilaku-perilaku khusus yang akan menjadi dasar penyusunan soal. Artinya, penulisan butir-butir soal dalam instrumen harus berpedoman pada kisi-kisi yang telah dibuat. Produk tabel spesifikasi beserta butir soal yang telah ditulis diberikan kepada expert untuk ditelaah dan divalidasi. Inilah yang dalam penelitian ini disebut dengan validitas konstruk. Instrumen dikatakan memenuhi syarat validitas konstruk, jika butir-butir pertanyaan yang membangun instrumen dinilai oleh ahli dan dinyatakan telah menggambarkan apa yang hendak diukur (Arikunto, 2002).

Validitas isi (content validity) merupakan validitas yang diperhitungkan melalui pengujian terhadap isi alat ukur dengan analisis rasional. Dalam penelitian ini validitas isi lebih diarahkan kepada penilaian kebenaran isi atau kebenaran konsep-konsep yang terkandung di dalam instrumen. Cara yang ditempuh untuk memperoleh data validitas ini adalah didasarkan pada penilaian mengenai substansi isi alat ukur. Apabila substansi isi alat ukur telah diketahui tidak mengandung fakta, konsep, prinsip yang salah (miskonsepsi), maka dapat dikatakan validitas isi telah terpenuhi. Selain kebenaran isi yang terkandung di dalam soal, kalimat yang digunakan untuk mengkomunikasikan pesan yang tersirat di dalam soal harus sederhana dan mudah dipahami (lugas).

Instrumen pendeteksi pemahaman wacana, selain harus memenuhi syarat validitas konstruk dan isi harus juga memenuhi syarat validitas psikometrik.Validitas psikometrik dibedakan atas validitas psikometrik secara individual (per butir) dan validitas psikometrik keseluruhan item sebagai kesatuan tes yang meliputi reliabilitas, validitas, dan daya diskriminasinya (Supratiknya, 2014). Validitas psikometrik ditetapkan melalui uji coba instrumen pada sasaran terbatas. Langkah ini oleh Supratiknya (2014) disebut sebagai tahap empiris-statistis.

Tahap empiris-statistis ini untuk memeriksa pemenuhan syarat-syarat psikometrik secara individual (per butir) yang meliputi validitas, daya diskriminasinya dan pemeriksaan pemenuhan syarat-syarat psikometrik keseluruhan item sebagai kesatuan tes, reliabilitas. Instrumen yang memenuhi syarat validitas dan reliabilitas oleh Arikunto (2002) dinyatakan sebagai instrumen yang baik.

Validitas prediktif (predictive validity) menguji apakah instrumen pendeteksi pemahaman wacana siswa menghasilkan data ukur yang berfungsi sebagai prediktor bagi data yang diukur oleh instrumen pendeteksi miskonsepsi siswa, mengakomodasi terminologi Kerlinger (1990).Validitas prediktif dalam penelitian ini diuji dengan 2 (dua) cara analisis, yaitu: (1) analisis deskriptif dan (2) analisis keterhubungan menggunakan chi square. Untuk keperluan uji validitas prediktif atas perangkat yang dikembangkan dibutuhkan data yang merepresentasi kemampuan siswa memahami wacana ilmiah tentang atom dan beban miskonsepsinya pada topik struktur atom. Data itu diperoleh bersamaan dengan tahap pengujian validitas psikometrik.

\section{METODE PENELITIAN}

Pengembangan instrumen pendeteksi kemampuan pemahaman wacana siswa mengikuti rekomendasi Suryabrata (2000). Pengembangan instrumen tersebut 
terdiri atas tahapan: (1) pengembangan spesifikasi tes, (2) penulisan soal, (3) penelaahan soal, (4) perakitan soal (untuk keperluan uji coba), (5) uji coba tes, (6) analisis butir soal, dan (7) seleksi dan perakitan soal.

Variabel dalam penelitian ini antara lain: validitas konstruk, validitas isi, kelugasan kalimat dan tata tulis, validitas psikometrik (validitas butir dan reliabilitas), dan validitas prediktif. Untuk mendapatkan variabel prediktif dibutuhkan variabel lain yang dibedakan atas variabel prediktor dan variabel kriterium. Variabel prediktor terdiri atas kemampuan pemahaman wacana dan sebagai variabel kriterium adalah jumlah miskonsepsi siswa pada konsep-konsep struktur atom. Subyek penelitian untuk validitas isi, konstruk dan kelugasan bahasa adalah para ahli di bidang yang relevan dengan produk instrumen yang dikembangkan, yang dalam penelitian ini adalah 4 (empat) orang dosen kimia untuk instrumen yang di dalamnya memuat konsep-konsep kimia. Subjek penelitian untuk validitas psikometrik dan validitas prediktif adalah 130 orang siswa kelas XI dari dua sekolah, yaitu SMAN Sumberrejo dan SMAN Model Terpadu, kabupaten Bojonegoro. Siswa kelas XI dipilih sebagai subyek penelitian karena siswa ini telah mengalami pembelajaran struktur atom.

Teknik pengumpulan data dan instrumen penelitian secara ringkas dibuat dalam bentuk matriks sebagaimana dalam Tabel 1.

Tabel 1. Teknik Pengumpulan Data dan Instrumen Penelitian

\begin{tabular}{|c|c|c|c|}
\hline No. & $\begin{array}{c}\text { Variabel } \\
\text { Penelitian }\end{array}$ & $\begin{array}{c}\text { Teknik Pengumpulan } \\
\text { Data } \\
\end{array}$ & Instrumen Pengumpul Data \\
\hline 1 & $\begin{array}{l}\text { Validitas } \\
\text { Konstruk }\end{array}$ & $\begin{array}{lr}\text { Expert } & \text { Judgement } \\
\text { berupa } & \text { penilaian } \\
\text { tertutup } & \end{array}$ & $\begin{array}{l}\text { - Lembar validasi (bentuk check list) } \\
\text { - Naskah Soal Pemahaman Wacana Siswa dan } \\
\text { naskah soal pendeteksi miskonsepsi siswa, } \\
\text { masing-masing dilengkapi blue print/kisi-kisi }\end{array}$ \\
\hline 2 & $\begin{array}{l}\text { Validitas Isi, } \\
\text { Kelugasan } \\
\text { kalimat dan } \\
\text { Tata Bahasa }\end{array}$ & $\begin{array}{lr}\text { Expert } & \text { Judgement } \\
\text { berupa penilaian } \\
\text { terbuka/catatan editing } \\
\text { yang diberikan oleh ahli }\end{array}$ & $\begin{array}{l}\text { - Lembar telaah } \\
\text { - Naskah Soal Pemahaman Wacana Siswa dan } \\
\text { naskah soal pendeteksi miskonsepsi siswa }\end{array}$ \\
\hline 3 & $\begin{array}{l}\text { Validitas } \\
\text { Psikometrik }\end{array}$ & Tes tertulis & $\begin{array}{lrrrr}\text { Naskah Soal Pemahaman } & \text { Wacana Siswa dan } \\
\text { naskah soal pendeteksi } & \text { miskonsepsi siswa } \\
\text { dilengkapi lembar jawaban } & & \end{array}$ \\
\hline 4 & Reliabilitas & $\begin{array}{l}\text { Tes tertulis (konsistensi } \\
\text { internal) }\end{array}$ & $\begin{array}{lrrr}\text { Naskah Soal Pemahaman } & \text { Wacana Siswa dan } \\
\text { naskah soal pendeteksi } & \text { miskonsepsi siswa } \\
\text { dilengkapi lembar jawaban } & & \end{array}$ \\
\hline 5 & Daya Beda & Tes tertulis & $\begin{array}{lrrrr}\text { Naskah Soal Pemahaman } & \text { Wacana Siswa dan } \\
\text { naskah soal pendeteksi } & \text { miskonsepsi } & \text { siswa } \\
\text { dilengkapi lembar jawaban } & & \end{array}$ \\
\hline 6 & $\begin{array}{l}\text { Tingkat } \\
\text { Kesukaran }\end{array}$ & Tes tertulis & $\begin{array}{lrrr}\text { Naskah Soal Pemahaman } & \text { Wacana Siswa dan } \\
\text { naskah soal pendeteksi } & \text { miskonsepsi siswa } \\
\text { dilengkapi lembar jawaban } & & \end{array}$ \\
\hline 7 & $\begin{array}{l}\text { Validitas } \\
\text { Predikif }\end{array}$ & Tes tertulis & $\begin{array}{lrrrr}\text { Naskah Soal Pemahaman } & \text { Wacana Siswa dan } \\
\text { naskah soal pendeteksi } & \text { miskonsepsi siswa } \\
\text { dilengkapi lembar jawaban } & & & \end{array}$ \\
\hline 8 & Keterbacaan & Pengisian angket siswa & $\begin{array}{l}\text { Angket keterbacaan siswa bentuk setengah terbuka. } \\
\text { Naskah }\end{array}$ \\
\hline
\end{tabular}

Teknik analisis data dalam penelitian ini secara ringkas dibuat dalam bentuk matriks, sebagaimana dalam Tabel 2.

Tabel 2. Teknik Analisis Data

\begin{tabular}{|c|l|l|}
\hline No. & \multicolumn{1}{|l|}{ Variabel Penelitian } & \multicolumn{1}{c|}{ Pendekatan/Teknik Analisis Data } \\
\hline 1 & Validitas Konstruk & Analisis rasional \\
\hline 2 & $\begin{array}{l}\text { Validitas Isi, Kelugasan } \\
\text { kalimat dan Tata Bahasa }\end{array}$ & Analisis rasional \\
\hline 3 & Validitas Psikometrik & Korelasi skor item-total dengan formula product-moment Pearson \\
\hline 4 & Reliabilitas & Statistik berbasis varians dengan formula alpha Cronbach \\
\hline 5 & Daya Beda & Korelasi skor item-total dengan formula biserial \\
\hline 6 & Tingkat Kesukaran & Statistik deskriptif: proporsi subjek yang memilih kunci jawaban \\
\hline 7 & Validitas Predikif & $\begin{array}{l}\text { Statistik deskriptif dan statistik inferensial chi square dan uji } \\
\text { regeresi berganda. }\end{array}$ \\
\hline 8 & Keterbacaan & $\begin{array}{l}\text { Menghitung indeks keterbacaan dengan menggunakan Gunning } \\
\text { Fog Index }\end{array}$ \\
\hline
\end{tabular}


Persentasi skor untuk validitas konstruksi diinterpretasikan dengan menggunakan kategori persentase penilaian validitas konstruk menurut Arikunto (1998:246) adalah sebagai berikut: 76\% 100\% (Valid), 56\% - 75\% (Cukup valid), 40\% - 55\% (Kurang valid), dan kurang dari $40 \%$ (Tidak valid).

Pada aspek validitas isi, butir instrumen dikatakan valid jika ada catatan dari validator yang mengindikasikan bahwa butir-butir instrumen tidak mengandung kesalahan konsep. Tidak adanya komentar dan saran perbaikan dari validator berarti validator tidak melihat adanya kesalahan konsep atau kesalahan substansi isi dari naskah instrumen. Pada segi bahasa, butir instrumen dikatakan layak jika ada catatan dari validator yang menerangkan bahwa kalimat-kalimat pada instrumen dapat dipahami di mana kriterianya adalah rumusan pertanyaan ditulis dalam kaidah bahasa Indonesia, kalimat soal tidak mengandung arti ganda dan rumusan kalimat pertanyaan komutatif atau menggunakan bahasa sederhana bagi siswa. Tidak adanya catatan revisi dan saran perbaikan dari validator berarti validator tidak melihat adanya kesalahan tata bahasa pada naskah instrumen.

Setiap butir soal memenuhi syarat validitas bila memiliki kesejajaran atau korelasi positif dengan skor total, sehingga dari validitas suatu perangkat tes dapat diselidiki lebih lanjut butir-butir soal yang mendukung dan tidak mendukung. Dalam menginterpretasi nilai $r_{x y}$ dibagi ke dalam klasifikasi berikut: $0,80<r_{x y} \leq 1,00$ (Validitas sangat tinggi), $0,60<r_{x y} \leq 0,80$ (Validitas tinggi), $0,40<r_{x y} \leq 0,60$ (Valid), $0,20<r_{x y} \leq 0,40$ (Validitas rendah), $0,00<r_{x y} \leq 0,20$ (Validitas sangat rendah), dan $r_{x y} \leq 0,00$ (Tidak valid). Instrumen dinyatakan reliabel jika alpha Cronbach $\geq 0,60$.

Instrumen pendeteksi pemahaman wacana siswa dinyatakan memenuhi syarat validitas prediktif jika data ukur yang diperoleh dengan instrumen ini terbukti baik secara deskriptif maupun inferensial memiliki keterhubungan yang signifikan dengan data ukur beban miskonsepsi siswa. Bentuk-bentuk keterhubungan dan kontribusi yang seharusnya berlaku adalah sebagai berikut: (1) diagram (dalam hal ini histrogram) menunjukan adanya persentase rata-rata siswa miskonsepsi didominasi oleh siswa dengan level pemahaman wacana rendah, (2) hasil uji Chi Square menunjukan ada hubungan yang signifikan antara skor kemampuan siswa yang diukur dengan instrumen pendeteksi pemahaman wacana siswa dengan jumlah miskonsepsi pada siswa (nilai $p$-value yang lebih kecil dari pada $\alpha=0,05$ ).

\section{HASIL PENELITIAN DAN DISKUSI}

A. Validitas Logis

Hasil penilaian ahli (expert judgement) atas kelayakan butir-butir pertanyaan yang jawabannya menggambarkan pemahaman wacana siswa diringkaskan pada Tabel 3.

Tabel 3. Hasil Penilaian Validasi Konstruksi Instrumen Pendeteksi Pemahaman Wacana Siswa (PW)

\begin{tabular}{|c|c|c|c|c|c|c|}
\hline \multirow[t]{2}{*}{$\begin{array}{c}\text { No } \\
\text { butir }\end{array}$} & \multicolumn{4}{|c|}{ Validator } & \multirow[t]{2}{*}{$\begin{array}{l}\text { Persen } \\
\text { skor } \\
(\%) \\
\end{array}$} & \multirow[t]{2}{*}{$\begin{array}{l}\text { Kriteria } \\
\text { interpretasi } \\
\text { skor }\end{array}$} \\
\hline & 1 & 2 & 3 & 4 & & \\
\hline 1 & 3 & 5 & 5 & 5 & 90,0 & Valid \\
\hline 2 & 5 & 5 & 4 & 4 & 90,0 & Valid \\
\hline 3 & 3 & 5 & 5 & 4 & 85,0 & Valid \\
\hline 4 & 3 & 5 & 5 & 2 & 75,0 & Cukup valid \\
\hline 5 & 4 & 4 & 5 & 4 & 85,0 & Valid \\
\hline 6 & 3 & 2 & 4 & 4 & 65,0 & Cukup valid \\
\hline 7 & 4 & 3 & 4 & 5 & 80,0 & Valid \\
\hline 8 & 4 & 4 & 5 & 4 & 85,0 & Valid \\
\hline 9 & 4 & 4 & 4 & 4 & 80,0 & Valid \\
\hline 10 & 4 & 4 & 5 & 4 & 85,0 & Valid \\
\hline 11 & 4 & 5 & 5 & 4 & 90,0 & Valid \\
\hline 12 & 3 & 4 & 5 & 4 & 80,0 & Valid \\
\hline 13 & 4 & 5 & 4 & 4 & 85,0 & Valid \\
\hline 14 & 4 & 4 & 4 & 4 & 80,0 & Valid \\
\hline 15 & 4 & 4 & 5 & 3 & 80,0 & Valid \\
\hline 16 & 3 & 4 & 5 & 3 & 75,0 & Cukup valid \\
\hline 17 & 4 & 4 & 4 & 5 & 85,0 & Valid \\
\hline 18 & 3 & 4 & 5 & 2 & 70,0 & Cukup valid \\
\hline 19 & 4 & 4 & 4 & 4 & 80,0 & Valid \\
\hline 20 & 4 & 5 & 4 & 3 & 80,0 & Valid \\
\hline 21 & 4 & 4 & 4 & 2 & 70,0 & Cukup valid \\
\hline 22 & 4 & 4 & 4 & 2 & 70,0 & Cukup valid \\
\hline 23 & 4 & 5 & 4 & 3 & 80,0 & Valid \\
\hline 24 & 4 & 4 & 4 & 4 & 80,0 & Valid \\
\hline 25 & 4 & 5 & 4 & 5 & 90,0 & Valid \\
\hline
\end{tabular}

Hasil penilaian ahli atas kelayakan butir-butir pertanyaan yang jawabannya menggambarkan pemahaman wacana struktur atom adalah bahwa dari 25 butir soal yang membangun instrumen 19 butir atau $76 \%$ dari total butir soal dinilai valid oleh ahli, sedangkan enam butir soal (24\%) mendapatkan penilaian cukup valid. Butir soal yang dinilai cukup valid dan valid dapat digunakan dalam pengukuran pemahaman wacana siswa. Implikasinya adalah bahwa instrumen yang dikembangkan telah dapat dipakai untuk mengukur indikator pemahaman wacana.

Terhadap kebenaran isi atau konsep-konsep yang terkandung di dalam instrumen pendeteksi pemahaman wacana, validator menyatakan tidak ada konsep yang salah. Keempat validator pun tidak menuliskan komentar dan saran perbaikan. Peneliti berasumsi 
bahwa tidak adanya komentar dan saran perbaikan dari validator berarti validator tidak melihat adanya kesalahan konsep atau kesalahan substansi isi dari naskah instrumen pendeteksi pemahaman wacana siswa. Dengan demikian instrumen pendeteksi pemahaman wacana siswa dapat dinyatakan sudah memenuhi validitas isi. Instrumen yang dikembangkan layak secara konseptual atau substansial digunakan mengungkap kemampuan pemahaman wacana siswa.

Keempat validator berpendapat, melalui catatan tertulis pada lembar validasi bahwa secara umum bahasa yang digunakan dalam instrumen tidak terlalu kompleks sehingga dapat dipahami oleh siswa, namun masih ada perbaikan yang harus dilakukan. Catatan perbaikan yang diberikan validator antara lain (1) pada butir soal nomor 2, kata "atom-atom" yang memiliki makna majemuk dinilai tidak tepat untuk menyatakan emisi suatu unsur dan harus diganti, (2) kata "perbedaan energi" pada pilihan jawaban d butir soal nomor 4 diganti dengan istilah yang lebih tepat, (3) Pertanyaan butir soal nomor 7 dan 10 perlu diperjelas rujukan wacananya dengan menuliskan nomor wacana yang dimaksud, dan (4) penulisan lambang ion titanium $\left(\mathrm{Ti}^{+}\right)$ pada butir soal nomor 25 secara ukuran font tidak cukup jelas.

Dengan demikian instrumen pendeteksi pemahaman wacana yang sedang dikembangkan telah memenuhi syarat kelugasan dalam penyampaian pesan. Kelugasan dalam penyampaian pesan akan memfasilitasi terjadinya interaksi dan keterlibatan siswa dengan bahasa tertulis, demikian pernyataan Caldwell (2008). Jika terjadi interaksi yang baik akan terjadi proses pengekstraksian makna oleh seseorang dari bahasa tertulis sesuai dengan pendapat Kudo \& Bazan (2009). Perbaikan-perbaikan mengikuti catatan yang diberikan validator pada bagian-bagian yang diberi tandai oleh telah dilakukan oleh peneliti untuk penyempurnaan instrumen.

\section{B. Validitas Psikometrik}

Instrumen pengukur atribut psikologis, selain harus memenuhi syarat validitas konstruk dan isi harus juga memenuhi syarat validitas psikometrik, seperti validitas dan reliabilitas. Indeks validitas untuk 25 butir soal pendeteksi pemahaman wacana siswa ditetapkan melalui uji coba I.

Berdasar data indeks validitas masing-masing soal dapat diberikan analisis bahwa dari 25 butir soal yang membangun instrumen pendeteksi pemahaman wacana 22 butir soal dinyatakan valid dan 3 (tiga) butir soal dinyatakan tidak valid. Tiga butir soal yang tidak valid adalah soal nomor 6, 16 dan 21, yang selanjutnya dieliminasi dan tidak digunakan untuk analisis lebih lanjut, termasuk dalam perhitungan reliabilitas tes yang diestimasi melalui komputasi. Jadi, jumlah butir soal pendeteksi pemahaman wacana yang diterima dan digunakan adalah 22 butir soal. Keduapuluh dua butir soal ini diuji dalam uji coba II untuk memverifikasi hasil analisis butir sebelumnya dan diperoleh hasil sebagaimana disajikan pada Tabel 6.

Tabel 6 Hasil Perhitungan Indeks Kesukaran dan Daya Beda Instrumen Pendeteksi Pemahaman Wacana Siswa

\begin{tabular}{|c|c|c|c|c|c|c|c|}
\hline Item & $\begin{array}{c}\text { Tk. } \\
\text { Pemahaman }\end{array}$ & IK & Kategori & $\begin{array}{c}\text { Daya } \\
\text { beda }\end{array}$ & Kategori & Validitas & Ket. \\
\hline 1 & Faktual & 0,515 & Sedang & 0,519 & Baik & 0,414 & Valid \\
\hline 2 & Interpretif & 0,477 & Sedang & 0,595 & Baik & 0,474 & Valid \\
\hline 3 & Faktual & 0,615 & Sedang & 0,49 & Baik & 0,385 & Valid \\
\hline 4 & Faktual & 0,669 & Sedang & 0,64 & Baik & 0,493 & Valid \\
\hline 5 & Aplikatif & 0,169 & Sukar & 0,751 & Baik & 0,505 & Valid \\
\hline 7 & Faktual & 0,515 & Sedang & 0,611 & Baik & 0,487 & Valid \\
\hline 8 & Interpretif & 0,831 & Mudah & 0,771 & Baik & 0,519 & Valid \\
\hline 9 & Interpretif & 0,862 & Mudah & 0,597 & Baik & 0,382 & Valid \\
\hline 10 & Faktual & 0,431 & Sedang & 0,469 & Baik & 0,372 & Valid \\
\hline 11 & Aplikatif & 0,215 & Sukar & 0,598 & Baik & 0,426 & Valid \\
\hline 12 & Faktual & 0,408 & Sedang & 0,504 & Baik & 0,398 & Valid \\
\hline 13 & Aplikatif & 0,392 & Sedang & 0,758 & Baik & 0,597 & Valid \\
\hline 14 & Faktual & 0,477 & Sedang & 0,59 & Baik & 0,471 & Valid \\
\hline 15 & Faktual & 0,462 & Sedang & 0,576 & Baik & 0,459 & Valid \\
\hline 17 & Faktual & 0,862 & Mudah & 0,688 & Baik & 0,44 & Valid \\
\hline 18 & Aplikatif & 0,808 & Mudah & 0,759 & Baik & 0,527 & Valid \\
\hline 19 & Faktual & 0,246 & Sukar & 0,527 & Baik & 0,385 & Valid \\
\hline 20 & Interpretif & 0,346 & Sedang & 0,679 & Baik & 0,526 & Valid \\
\hline
\end{tabular}




\begin{tabular}{|c|c|c|c|c|c|c|c|}
\hline Item & $\begin{array}{c}\text { Tk. } \\
\text { Pemahaman }\end{array}$ & IK & Kategori & $\begin{array}{c}\text { Daya } \\
\text { beda }\end{array}$ & Kategori & Validitas & Ket. \\
\hline 22 & Faktual & 0,092 & Sukar & 0,83 & Baik & 0,474 & Valid \\
\hline 23 & Interpretif & 0,269 & Sukar & 0,509 & Baik & 0,379 & Valid \\
\hline 24 & Aplikatif & 0,462 & Sedang & 0,762 & Baik & 0,607 & Valid \\
\hline 25 & Aplikatif & 0,469 & Sedang & 0,686 & Baik & 0,547 & Valid \\
\hline
\end{tabular}

Berdasar data dalam Tabel 6 dapat diberikan analisis bahwa 22 butir soal dinyatakan valid. Kedua, 22 butir soal yang dikembangkan memiliki daya beda yang baik. Ke 22 butir soal yang membangun instrumen pendeteksi pemahaman wacana siswa dapat digunakan untuk membedakan siswa level rendah dan level tinggi. Ketiga, instrumen pendeteksi pemahaman wacana siswa dibangun oleh butir-butir soal dengan tiga tingkat kesukaran, yaitu mudah, sedang, dan sukar. Perbandingan proporsi butir soal mudah, sedang, dan sukar pada instrumen pendeteksi pemahaman wacana siswa merupakan proporsi yang baik karena sangat baik ketika digunakan untuk memotret distribusi kemampuan siswa pada kelas normal. Artinya, dalam kelas normal terdapat siswa yang berkemampuan kurang, sedang, dan tinggi.

Reliabilitas instrumen ditetapkan berdasar nilai koefisien Cronbach' alfa terhadap data ukur hasil uji coba lapangan. Nilai koefisien Cronbach' alfa yang diperoleh adalah $\mathrm{r}=0,826$ dengan standard error 1,218 yang merupakan angka relatif kecil. Berdasar nilai ini dapat disimpulkan bahwa instrumen pendeteksi persepsi siswa telah memenuhi syarat reliabilitas, instrumen dinyatakan memiliki karakteristik ajeg untuk digunakan dalam pengukuran atribut psikologis.

Dari aspek keterbacaan, instrumen pendeteksi pemahaman wacana siswa telah teruji tingkat keterbacaannya baik. Tingkat keterbacaan direpresentasikan oleh sebuah nilai indeks yang dihitung dengan menggunakan Gunning Fog Index. Hasil analisis memperlihatkan skor indeks 9,90 yang menunjukan bahwa naskah soal sangat mudah dipahami oleh siswa tingkat SMA. Dengan demikian dapat disimpulkan bahwa instrumen pendeteksi pemahaman wacana siswa memiliki kategori keterbacaan yang sangat baik.

Instrumen pendeteksi pemahaman wacana siswa pada struktur atom, dengan 22 butir soal telah memenuhi syarat validitas psikometrik. Kualitas masing-masing butir soal dan kualitas instrumen sebagai himpunan butir-butir soal telah diuji dan dinyatakan memenuhi standar yang ditetapkan. Instrumen ini dapat dipakai oleh para praktisi pembelajaran kimia untuk memetakan pemahaman wacana siswa, jika ditinjau dari aspek psikometrik dan keterbacaan.

\section{Validitas Prediktif}

Validitas prediktif (predictive validity) menguji apakah instrumen pendeteksi pemahaman wacana siswa menghasilkan data ukur yang berfungsi sebagai prediktor bagi data yang diukur oleh instrumen pendeteksi miskonsepsi siswa. Diagram yang memvisualisasi persentase siswa dengan tingkatan pemahaman wacana tertentu yang mengalami miskonsepsi pada keempat konsep struktur atom yang diujikan disajikan pada Gambar 1. Data jumlah miskonsepsi setiap siswa sasaran uji coba, yang selanjutnya disebut beban miskonsepsi disajikan pada Lampiran 14. Tigabelas (13) siswa yang dikategorikan memiliki pemahaman wacana rendah (warna hijau), 12 (duabelas) anak (92,3\%) mengalami miskonsepsi pada konsep Tingkat energi. Demikian seterusnya cara membaca Gambar 1.

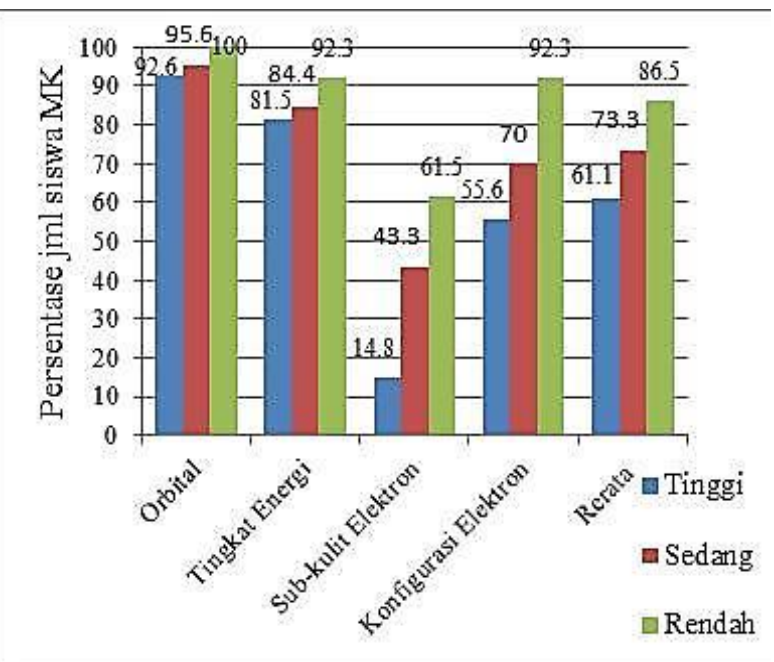

Gambar 1. Persentase Miskonsepsi Siswa pada Keempat Konsep Struktur Atom

Berdasar data dalam Gambar 1 dapat diberikan hasil analisis bahwa persentase siswa miskonsepsi terbesar pada keseluruhan konsep struktur atom terjadi pada siswa dengan pemahaman wacana rendah. Jika dilihat dari nilai rerata, nampak bahwa semakin rendah kemampuan siswa memahami wacana semakin tinggi persentase terjadinya miskonsepsi. Siswa yang memiliki kemampuan pemahaman wacana rendah memiliki peluang tertinggi mengalami miskonsepsi pada struktur atom. Jadi, telah dimiliki bukti bahwa skor siswa yang diukur menggunakan instrumen pendeteksi pemahaman wacana telah memiliki keterhubungan dengan skor yang digali menggunakan 
instrumen pendeteksi miskonsepsi siswa. Instrumen pendeteksi pemahaman wacana siswa disimpulkan secara deskriptif telah memenuhi syarat validitas prediktif. Simpulan awal ini dicoba diverifikasi menggunakan analisis inferensial chi square.

\section{Hasil Analisis Chi Square}

Hubungan antara tingkatan persepsi siswa dan tingkatan beban miskonsepsi siswa pada struktur atom disajikan pada Tabel 7.

Tabel 7. Crosstab Tingkat Pemahaman Wacana dan Tingkat Beban Miskonsepsi Siswa

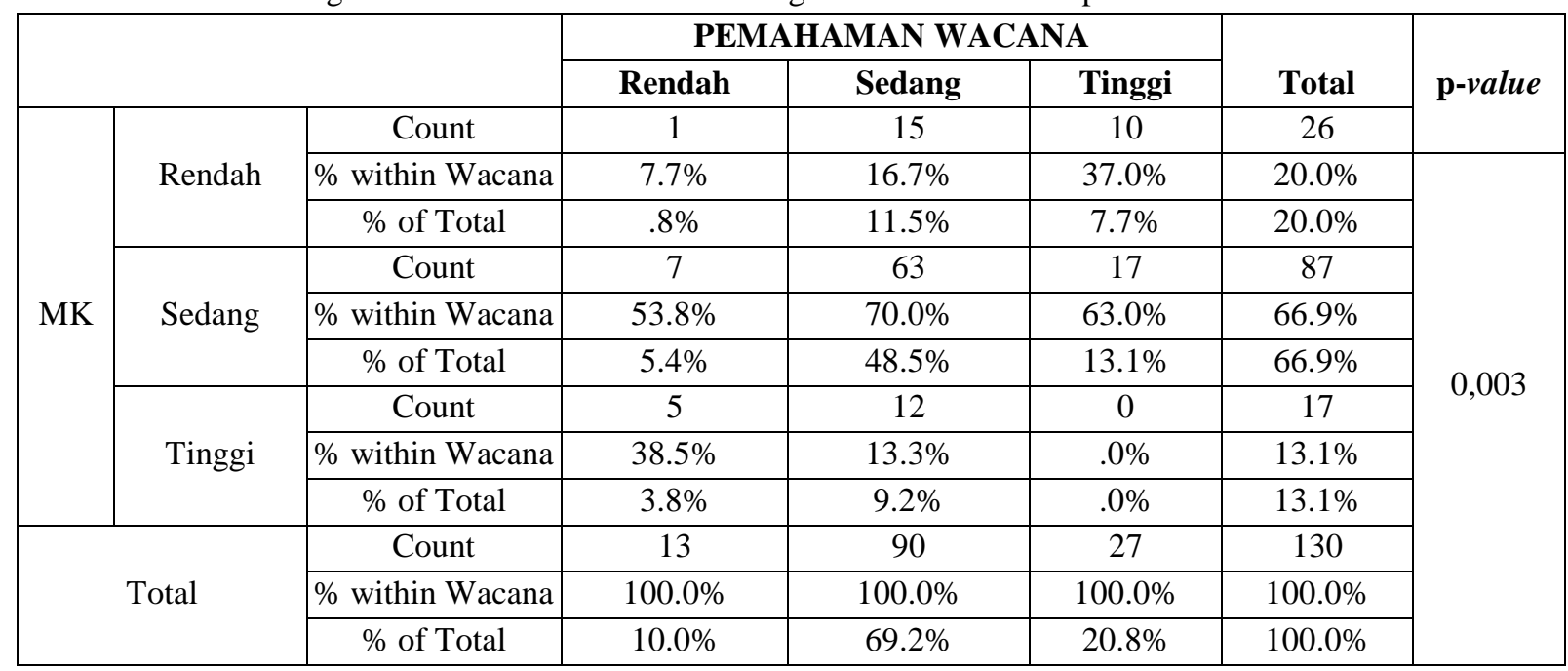

Berdasar data dalam Tabel 7 terdapat hubungan yang signifikan antara level pemahaman wacana siswa dengan level beban miskonsepsi siswa pada struktur atom. Hasil analisis inferensial memperkuat hasil analisis deskriptif. Fakta adanya keterhubungan ini adalah bukti empiris yang memperkuat teori yang telah dikemukakan oleh para pakar di bidang pendidikan seperti Ibrahim (2012) juga Chi et al. (1994). Instrumen pendeteksi pemahaman wacana siswa disimpulkan telah memenuhi syarat validitas prediktif. Implikasinya adalah bahwa para pembelajar telah dapat menggunakan instrumen ini untuk memetakan pemahaman wacana siswa ketika model mental siswa ditetapkan sebagai faktor penyebab miskonsepsi siswa pada struktur atom. Hasil pemetaan pemahaman wacana siswa itu selanjutnya dapat digunakan sebagai bahan pertimbangan dalam perencanaan perbaikan miskonsepsi siswa pada struktur atom.

Diskusi lebih lanjut terkait pemahaman wacana dan miskonsepsi dapat dinarasikan seperti berikut ini. Penggunaan prakonsepsi yang sudah ada sebelumnya (misalnya, latar belakang pengetahuan yang salah) dalam memahami wacana dapat menimbulkan terbangunnya sebuah model mental yang tidak akurat, yang berbeda dengan model ilmiah yang dimaksudkan oleh penulis teks (Chi et al., 1994). Menurut Horton prakonsepsi siswa membentuk kerangka pikiran, kerangka pikiran itu menjadi suatu scaffolding ketika siswa membangun rangkaian pengetahuan berikutnya. Informasi baru dan ide-ide yang diterima siswa senantiasa ditafsirkan dan disusun sedemikian agar sesuai dengan scaffolding yang telah ada. Konsepsi ini membentuk jalur fisik aktual yang menetap dalam otak.
Arsitektur kognitif otak ini menjadi permanen dan tidak dapat dihapus. Jika harus diubah sebenarnya hanya melapisi dengan jalur fisik aktual baru. Dengan demikian tidak mengherankan jika terdapat kesulitan mengubah konsepsi siswa yang salah (miskonsepsi) menjadi konsepsi yang dapat diterima secara ilmiah (true concept). Siswa malahan mencangkokkan pengetahuan barunya ke dasar yang secara konseptual salah (Horton, 2004).

Lebih lanjut diketahui dua jenis pemahaman, pemahaman literal dan pemahaman inferensial. Pemahaman literal berpusat pada pengenalan atau memunculkan rincian utama, ide utama, urutan, atau sebab-akibat, dari informasi yang tertulis secara eksplisit di dalam teks. Pemahaman inferensial memerlukan pembuatan hubungan logis antar fakta dalam teks, menyimpulkan peristiwa, membuat generalisasi, menafsirkan fakta-fakta, dan mengaitkan konten dengan pengetahuan sebelumnya atau pengalaman pribadi, dari informasi yang tersirat dalam teks (Kudo \& Bazan, 2009).

Dalam rangka untuk memahami teks atau wacana, pembaca perlu mengembangkan keterampilan membuat inferensi, di samping diperlukannya bekal pengetahuan awal yang cukup. Bagi siswa yang kemampuan membacanya rendah dan pengetahuan ilmiahnya sedikit, syarat-syarat bagi kemampuan menyimpulkan seperti itu menjadi masalah serius bagi siswa (Lien, 2013). Selain itu, Best \& Ozuru (2005) menambahkan bahwa teks ilmiah biasanya bersifat low cohesion, yang berarti bahwa untuk memahami teks seperti itu membutuhkan pembaca yang mampu menghasilkan banyak simpulan. 
Implikasinya adalah bahwa, bagi guru yang merencanakan perbaikan miskonsepsi siswa dengan mempertimbangkan modal pemahaman wacana siswa masih terdapat banyak hal yang harus diperhatikan. Hal yang masih harus diperhatikan antara lain: (1) prakonsepsi siswa yang salah, yang dapat menimbulkan terbangunnya sebuah model mental yang tidak akurat, yang berbeda dengan model ilmiah yang dimaksudkan oleh penulis teks, (2) prakonsepsi yang salah tetapi kemudian membentuk kerangka pikiran yang dijadikan siswa scaffolding ketika siswa membangun rangkaian pengetahuan berikutnya, dan (3) adanya jenis pemahaman pada siswa (pemahaman literal dan pemahaman inferensial).

\section{KESIMPULAN}

\section{A. Simpulan}

Telah dihasilkan instrumen pedeteksi pemahaman wacana siswa pada struktur atom yang telah memenuhi syarat validitas konstruk, validitas isi, kelugasan kalimat dan tata tulis, validitas psikometrik (validitas butir dan reliabilitas), dan validitas prediktif. Dengan dipenuhinya validitas prediktif bagi instrumen pendeteksi pemahaman wacana siswa terhadap beban miskonsepsi siswa pada struktur atom, maka dapat disimpulkan bahwa tujuan untuk mengembangkan instrumen pendeteksi faktor penyebab miskonsepsi siswa pada struktur atom, khususnya atribut pemahaman wacana siswa telah dinyatakan tercapai.

\section{B. Saran}

Atribut pemahaman wacana siswa yang mempunyai keterhubungan signifikan terhadap kriterium beban miskonsepsi siswa, maka dalam pengambilan kebijakan-kebijakan terkait dengan perbaikan miskonsepsi, guru harus mempertimbangkan level kemampuan siswa memahami wacana. Telah dimilikinya instrumen pendeteksi pemahaman wacana siswa, maka guru telah memiliki modal untuk mengetahui level kemampuan pemahaman wacana yang dimiliki para siswanya. Guru dapat memastikan bahwa siswa tidak mengembangkan model mental yang salah karena model mental sangat penting dalam memahami konsep-konsep dalam kimia. Pengetahuan atas pemahaman wacana siswa sangat membantu guru dalam merancang pembelajaran yang akan dilakukan, termasuk di dalamnya perbaikan miskonsepsi siswa.

\section{REFERENSI}

Al-Balushi, S. M., Ambusaidi, A. K., Al-Shuaili, A.H., Taylor, N. (2012). "Omani twelfth grade students' most common misconceptions in chemistry". Internasional Council of Associations for Science Education. Vol. 23, No.3, pp. 221-240
Arikunto, S. (2010). Prosedur Penelitian: Suatu Pendekatan Praktik. Jakarta: Rineka Cipta.

Arikunto, S. (2002). Metodologi Penelitian. Jakarta: Rineka Cipta.

Bao, L. Redish, E.F. (2001) Model Analysis: Assessing the Dynamics of Student Learning.

Best, RM., Rowe, M.,Ozuru, Y., McNamara, D.S. (2005). "Deep-Level Comprehension of Science Texts The Role of the Reader and the Text". Top Lang Disorders Vol. 25, No. 1, pp. 65-83

Bodner, G.M. and Domin, D.S. (2000). "Mental Models: The Role of Representations in Problem Solving in Chemistry". Paper presented at Department of Chemistry. Purdue University, West Lafayette

Caldwell, J.A.C. (2008). Comprehension Assessment A Classroom Guide. New York :The Guilford Press

Chi, M.T.H., De Leeuw, N., Chiu, M.H., Lavancher, C. (1994). "Eliciting Self Explanations Improves Understanding". Cognitive Science. University of Pittsburgh Vol 18.. Pp. 439-477.

Coll, R.K. and Taylor, N. (2002). "Mental Models In Chemistry: Senior Chemistry Students. Mental Models Of Chemical Bonding". Chemistry Education: Research And Practice In Europe . Vol. 3, No. 2, pp. 175-184

Dahar, R.W. (2011). Teori-teori Belajar \& Pembelajaran. Jakarta: Erlangga

Foliaki, V. (2010), Transparent Rings Atomic Model (TRAM). Diunduh pada 21 Oktober 2014 dari http://elearn.usp.ac.fj/file.php/13380/Week\%204 \%20Science\%20Mdoels/TRAM\%20Activity.pdf

Harrison, A. G., \& Treagust, D. F. (1996). Secondary students' mental models of atoms and molecules: implications for teaching chemistry. Science Education.

Horton, C. (2004). Student Preconceptions and Misconceptions in Chemistry (Student Alternative Conceptions in Chemistry. Modeling Instruction in High School Chemistry Action Research. Arizona State University.

Ibrahim, M. (2012). Konsep, Miskonsepsi dan Cara Pembelajarannya. Surabaya: Unesa University Press.

Kerlinger, EN. (1990). Azas-Azas Penelitian Behavioral Yogyakarta: Gajah Mada University Press.

Kudo, I. and Bazan, J. L. (2009). Measuring Beginner Reading Skills. Empirical Evaluation of Alternative Instruments and their Potential Use for Policymaking and Accountability. Policy Research Working Paper. The World Bank Latin America \& the Caribbean Region Human Development Department Education Sector, pp. 1-91. 
Lajium, D.A.D. (2013). Students' Mental Models of Chemical Reactions. A thesis submitted in fulfilment of the requirements for the Degree of Doctor of Philosophy at The University of Waikato. New Zealand

Laliyo, L.A.R. (2011). "Model mental Siswa dalam Memahami Perubahan Wujud Zat", Jurnal Penelitian dan Pendidikan, Vol. 8 No. 1.

Lien, Chi-Shun. (2013). "Text Coherence, Reading, Ability, And Childern's Scientific Understanding.". Bulletin of Educational Psicology. Vol. 44 No.4, pp. 875-904.

MacKinnon, G. R. (2000). Students' understanding of orbitals: A survey ERIC Document No: ED433248

Suryabrata, S. (2000). Pengembangan Alat Ukur Psikologis. Yogyakarta: Andi
Suharnan. (2000). Psikologi Kognitif. Surabaya: Srikandi

Supratiknya, A. (2014). Pengukuran Psikologis. Yogyakarta: Sanata Darma

Suyono, Amaria, Muchlis dan Setiarso, Pirim. (2013). Diseminasi Model Prevensi dan Kurasi Miskonsepsi Siswa pada Konsep Kimia. Laporan Hasil Penelitian Unggulan Perguruan Tinggi Tahun I (tidak dipublikasikan). Surabaya: Lembaga Penelitian.

Suyono, Amaria, Muchlis dan Setiarso, Pirim. (2014). Diseminasi Model Prevensi dan Kurasi Miskonsepsi Siswa pada Konsep Kimia. Laporan Hasil Penelitian Unggulan Perguruan Tinggi Tahun II (tidak dipublikasikan). Surabaya: Lembaga Penelitian. 